\title{
Sistem Kehadiran Biometrik Sidik Jari Menggunakan IoT yang Terintegrasi dengan Telegram
}

\author{
Adipta Martulandi ${ }^{1 *}$, Dedi Setiawan ${ }^{2}$ \\ 1,2 Binus Graduate Program, Master of Information Technology, \\ Bina Nusantara University, \\ Jakarta, Indonesia 11480 \\ adipta.martulandi@binus.ac.id; dedi.setiawan001@binus.ac.id \\ *Correspondence: adipta.martulandi@binus.ac.id
}

\begin{abstract}
The rapid development of technology today is very useful for humans in various aspects of life. One of the impacts of these technological developments is IoT (Internet of Things). Currently, IoT has been widely used in various fields such as manufacturing, offices, public transportation, and education. One of the uses of IoT in the field of education is to create a biometric attendance system using fingerprints. The purpose why use the fingerprints is to reduce cheating committed by students such as leaving absent. By using the fingerprint IoT attendance system, this is difficult to do because everyone has a different form of fingerprint. In addition, this project integrates fingerprint attendance with the Telegram messenger application. All fingerprints and student attendance data are stored on the website. Based on the experimental results, the success rate of this attendance system is $80 \%$, and the accuracy is $89 \%$.
\end{abstract}

Keywords: System Attendance; IoT; Education; Fingerprint

\footnotetext{
Abstrak - Pesatnya perkembangan teknologi saat ini sangat membantu manusia dalam berbagai aspek kehidupan. Salah satu dampak perkembangan teknologi tersebut adalah IoT (Internet of Things). Saat ini IoT sudah banyak dimanfaatkan di berbagai bidang seperti manufaktur, perkantoran, transportasi umum, dan pendidikan. Salah satu pemanfaatan IoT dalam bidang Pendidikan adalah penggunaan IoT untuk membuat sistem absensi biometrik menggunakan sidik jari. Tujuan dari penggunaan sidik jari adalah untuk mengurangi kecurangan yang dilakukan oleh siswa seperti titip absen. Dengan menggunakan sistem absensi IoT sidik jari hal tersebut sulit untuk dilakukan karena setiap orang memiliki bentuk sidikjari yang berbedabeda. Selain itu, project ini mengintegrasikan absensi sidik jari dengan aplikasi pengirim pesan Telegram. Seluruh data sidik jari dan absen siswa disimpan di dalam website. Berdasarkan hasil eksperimen didapatkan keberhasilan
}

sistem absensi ini sebesar $80 \%$, dan akurasi sebesar $89 \%$.

Kata Kunci: Absensi; IoT; Pendidikan; Sidik Jari

\section{PENDAHULUAN}

Perkembangan teknologi di era saat ini sudah sangat pesat, hal itu juga pastinya tidak dapat dipisahkan dalam kehidupan masyarakat. Salah satu bukti pesatnya perkembangan teknologi tersebut adalah dengan adanya pemanfaatan Internet of Things (IoT) dalam kehidupan sehari-hari. Menurut [1] Internet of Things atau dikenal juga dengan singkatan IoT, merupakan sebuah konsep yang bertujuan untuk memperluas manfaat dari konektivitas internet yang tersambung secara terus-menerus yang memungkinkan kita untuk menghubungkan mesin, peralatan, dan benda fisik lainnya dengan sensor jaringan dan aktuator untuk memperoleh data dan mengelola kinerjanya sendiri, sehingga memungkinkan mesin untuk berkolaborasi dan bahkan bertindak berdasarkan informasi baru yang diperoleh secara independen. Salah satu contoh IoT yang populer saat ini adalah smart home, yang merupakan teknologi pintar pengontrolan rumah dari jarak jauh.

Pendidikan merupakan salah suatu hal yang sangat penting dalam kehidupan, baik dari individu maupun kelompok. Menurut UU No. 20 tahun 2003 Pendidikan adalah usaha sadar dan terencana untuk mewujudkan suasana belajar dan proses pembelajaran agar peserta didik secara aktif mengembangkan potensi dirinya untuk memiliki kekuatan spiritual keagamaan, pengendalian diri, kepribadian, kecerdasan, akhlak mulia, serta keterampilan yang diperlukan dirinya, masyarakat, bangsa, dan Negara. Di era digitalisasi saat ini sistem Pendidikan di dunia terus 
mengalami perbaikan, baik dari sisi operasional maupun non-operasional. Salah satunya absensi, dimana sebagian besar Sekolah Dasar (SD) dan Sekolah Menengah Pertama (SMP) masih menerapkan absensi secara manual, sehingga masih sering terjadinya kesalahan dalam hal perekapan. Selain, itu juga masih adanya siswa-siswi yang bolos saat jam sekolah, dan hal tersebut terkadang tidak diketahui oleh orang tuanya. Sehingga, dengan perkembangan teknologi ini diharapkan dapat mengatasi masalah tersebut.

Berdasarkan uraian tersebut peneliti bermaksud untuk membuat prototype sistem absensi biometrik menggunakan sidik jari yang dapat terkoneksi dengan notifikasi telegram orang tua siswa. Sehingga diharapkan orang tua dapat melihat aktivitas anaknya di sekolah, seperti apakah siswa tersebut bolos atau tidak, dan di jam berapa siswa tersebut masuk maupun pulang.

\section{METODOLOGI PENELITIAN}

\subsection{Identifikasi Masalah}

Pendidikan merupakan salah satu aspek kehidupan yang sangat penting yang berguna bagi sumber daya manusia yang berkualitas dan mampu mengikuti perkembangan zaman yang semakin maju. Di era digitalisasi saat ini sangat mendukung terciptanya sistem pendidikan yang lebih baik karena berbagai teknologi canggih telah ditemukan. Salah satu aspek penting dalam suatu sistem pendidikan adalah sistem absensi dimana absensi ini digunakan untuk mengetahui apakah seorang siswa masuk kelas atau bolos kelas.

Dalam sistem absensi tradisional, sangat mudah bagi siswa untuk mengelabui sistem absensi dengan menyerahkan absensi kepada teman meskipun siswa tersebut tidak menghadiri kelas tetapi mengikuti kegiatan lain. Kejadian ini dapat terjadi karena sistem absensi tradisional masih belum memanfaatkan teknologi yang ada dan sistem masih manual tulis tangan. Hal inilah yang mendasari perlunya sistem absensi yang baik dan sulit untuk dicurangi. Salah satu sistem absensi yang dapat digunakan adalah sistem absensi menggunakan sidik jari. terintegrasi dengan internet, telegram, dan web server.

Penggunaan sistem absensi menggunakan sidik jari sangat sulit untuk di curangi karena setiap siswa memiliki sidik jari yang unik dan tentunya siswa tidak dapat meninggalkan absensi karena sidik jarinya berbeda. Dengan menggunakan teknologi ini selain dapat mengurangi kecurangan dalam absensi juga dapat membantu orang tua untuk mengontrol ketidakhadiran anaknya karena ketika siswa tidak hadir akan ada notifikasi telegram kepada orang tua.

\subsection{Studi Literatur}

Studi terkait absensi menggunakan sidik jari yang dilakukan oleh Nesha, Agung dan Deny memperlihatkan bahwa akurasi dari sistem sidik jari bisa mencapai angka $86,67 \%$ yang merupakan hasil yang sangat bagus [2].

Selain itu, menurut studi dari Tripti, Tomar, Umang, Swati dari India mendapatkan bahwa proses pengenalan sidik jari bagi siswa yang sudah terdaftar hanya membutuhkan waktu sekitar 0,1 detik sedangkan bagi siswa yang belum terdaftar membutuhkan waktu 3-4 detik. Untuk perbandingan, sistem absensi manual menurut studi tersebut membutuhkan waktu 2-3x lebih lama dari sistem absensi biometrik [3].

Keuntungan lain menggunakan sistem absensi biometric bisa mengambil absensi siswa dan merekamnya secara real time di server. Lalu setiap siswa bisa melihat persentase absensinya menggunakan Handphone [4]

\subsection{Arsitektur Sistem Kehadiran Biometrik}

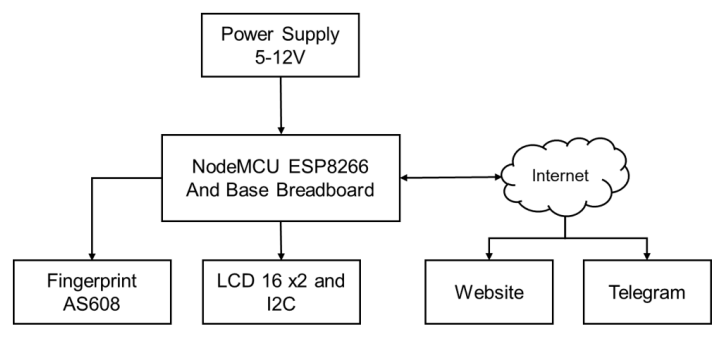

Gambar 1. Arsitektur Sistem Kehadiran Biometrik

Pada studi ini menggunakan microcontroller NodeMCU ESP8266 yang akan bertugas untuk mengatur sensor sidik jari, LCD, website, dan pengiriman pesan ke telegram secara berkesinambungan. Fingerprint berfungsi sebagai alat utama untuk absensi siswa. Sedangkan untuk LCD sebagai user interface untuk menampilkan proses absensi. Sedangkan, untuk website digunakan sebagai database untuk menyimpan data dari absensi siswa dan untuk proses pendaftaran sidik jari. Website tersebut juga dapat menampilkan dashboard summary pada proses pendaftaran, siswa akan diminta untuk memasukan ID Chat Telegram dari orangtuanya untuk pengiriman pesan pemberitahuan bahwa siswa tersebut sudah melakukan absen di sekolah.

\subsection{Alur Kerja Sistem Kehadiran Biometrik}

Pada Gambar 2 ditampilkan alur kerja dari sistem kehadiran biometrik ini :

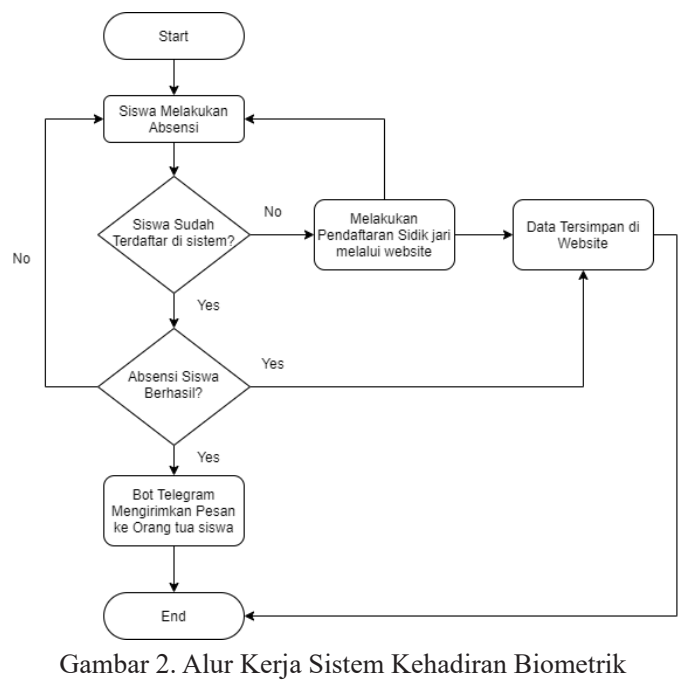

Gambar 2. Menjelaskan alur proses dari sistem absensi menggunakan sidik jari yang dimulai dengan siswa melakukan absensi. Jika siswa sudah terdaftar dan absensinya berhasil direkam, maka bot telegram akan 
otomatis mengirimkan pesan yang melalui telegram ke orang tua siswa yang memberitahukan bahwa siswa tersebut telah masuk sekolah dan mengisi absensi. Jika siswa tersebut belum terdaftar di sistem, maka siswa tersebut harus mendaftarkan sidik jari dan ID Chat Telegram orangtua melalui website. Jika proses pendaftaran berhasil, maka siswa bisa melanjutkan untuk proses absensi. Seluruh data dari absensi siswa disimpan di website. Data ini bisa kita olah lebih lanjut menjadi dashboard ada produk analitik lainya.

\subsection{Komponen Sistem Kehadiran Biometrik}

Berikut merupakan komponen-komponen yang dibutuhkan dalam membuat prototipe sistem absensi biometrik sidik jari :

Tabel 1. Komponen-Komponen yang dibutuhkan untuk Sistem Absensi Biometrik

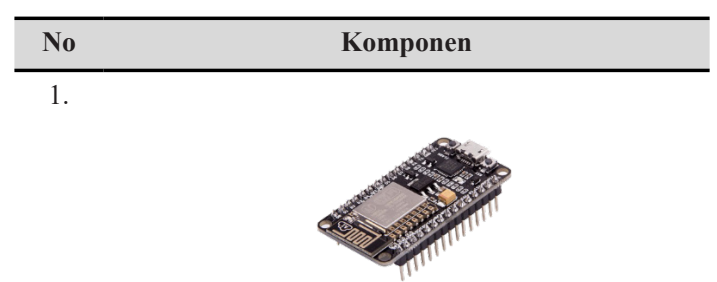

Gambar 3. NodeMCU ESP8266

Fungsi: sebagai microcontroller yang digunakan sebagai pengontrol maupun pengoprasi suatu sistem.

2.

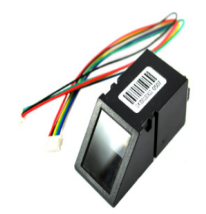

Gambar 4. Modul Fingerprint AS608

Fungsi: sebagai modul atau sensor yang digunakan untuk mengambil sidik jari siswa pada sistem absensi.

3.

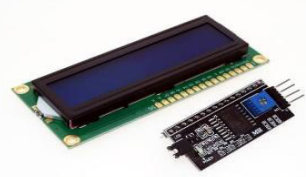

Gambar 5. LCD $16 \times 2$ dan I2C

Fungsi : sebagai papan yan menampilkan pesan saat siswa melakukan absensi atau lainnya.

4.

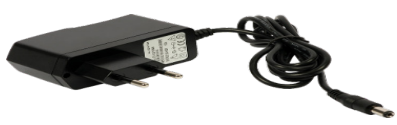

Gambar 6. Adaptor 9V 2A

Fungsi: sebagai pengubah tegangan AC menjadi DC atau penghubung arus listrik PLN ke rangkaian sistem absensi biometrik.

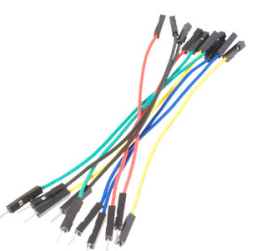

Gambar 7. Kabel Jumper

Fungsi: penghubung antar komponen pada breadboard.

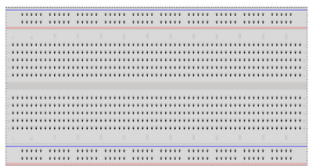

Gambar 8. Breadboard

Fungsi: Digunakan untuk membuat prototype rangkain tanpa harus menyolder.

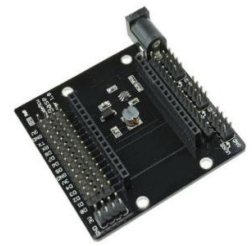

Gambar 9. Base Breadboard NodeMCU

Fungsi: untuk mempermudah konektivitas dengan perangkat lain karena ada banyak tambahan pin dan port

8 .

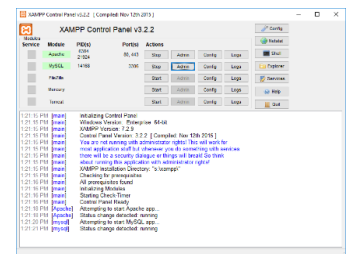

Gambar 10. XAMPP Software

Fungsi: sebagai server yang berdiri sendiri (localhost), yang terdiri atas program Apache HTTP Server, MySQL database.

9.

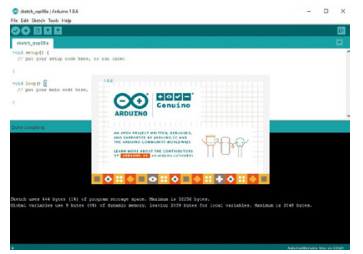

Gambar 11. Arduino IDE

Fungsi: sebagai software untuk memprogram sistem absensi biometrik pada microcontroller

10



Gambar 12. Telegram Messenger

Fungsi: untuk mengirim dan menerima pesan saat absensi siswa sukses dilakukan. 


\subsection{Prototype Sistem Kehadiran Biometrik}

Setelah merangkai semua komponen menjadi satu, didapatkan rangkaian prototipe sistem absensi biometrik menggunakan sensor fingerprint sebagai berikut :

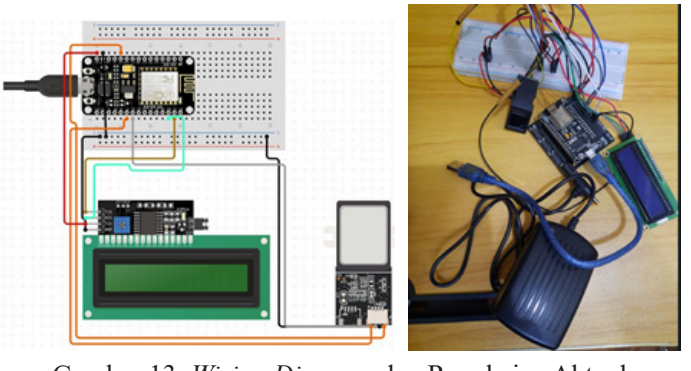

Gambar 13. Wiring Diagram dan Rangkaian Aktual Sistem Kehadiran Biometrik

Pada Gambar 13 kiri merupakan rangkain desain awal sistem ini pada circuito.io, dengan menggunakan desain tersebut dapat memudahkan dalam merangkai rangkain secara aktual saat membuat prototipe. Sedangkan untuk gambar sebelah kanan merupakan sistem absensi yang sudah dirangkai untuk masing-masing komponen, sehingga selanjutnya dapat dilakukan programing dan uploading program pada software ArduinoIDE. Jika upload sudah berhasil selanjutnya melakukan eksperimen untuk mencoba apakah sistem kehadiran ini sudah berhasil dan layak untuk digunakan. Tahapan awal adalah menambahkan user id pada website seperti tampilan Gambar 14 berikut :

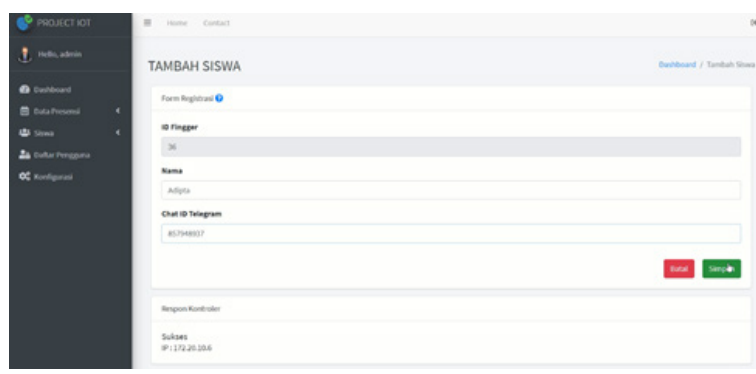

Gambar 14. User Interface Proses Pendaftaran Sidik Jari Melalui Website

Data yang diinput pada sistem meliputi, No ID, Nama siswa, ID telegram orang tua, serta perekaman sidik jari siswa. Jika sukses melakukan input data maka akan ada tampilan "sukses menambahkan ID baru" pada LCD sistem ini.
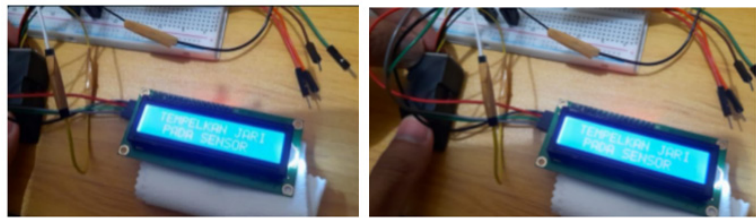

Gambar 15. Proses Absensi Pada Sistem Kehadiran Biometrik

Pada Gambar 15 ditampilkan contoh pesan notifikasi yang dikirimkan sistem absensi ini kepada orang tua murid yang ID Telegram nya sudah didaftarkan sebelumnya.
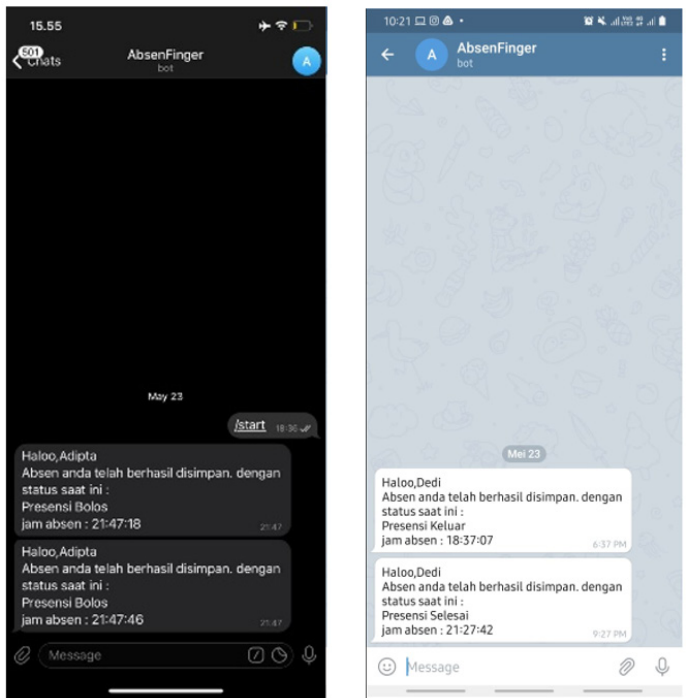

Gambar 15. Notifikasi Absensi Siswa Melalui Telegram

Informasi yang dikirimkan meliputi jam berapa siswa tersebut melakukan absensi, yang dibagi menjadi 3 absen masuk, absens keluar, serta absens bolos. Absensi masuk adalah absen yang dilakukan saat jam siswa masuk ke sekolah pagi hari, sedangkan untuk absen keluar adalah absensi yang dilakukan siswa saat jam pulang sekolah. Sedangkan absen bolos adalah kondisi dimana siswa hanya melakukan absen keluar saja saat jam pulang sekolah. Pengaturan jadwal masuk dan keluar pada sistem kehadiran ini dapat dilakukan pada website.

\section{HASIL DAN PEMBAHASAN}

Pada bab ini membahas terkait hasil eksperimen pada prototipe absensi yang telah dibuat sebelumnya. Eksperimen dilakukan pada 2 sidik jari (akun siswa), yang sebelumnya sudah didaftarkan pada sistem melalui website. Pada masing-masing sidik jari jari tersebut dilakukan eksperimen sebanyak 20 kali, dengan cara melakukan absensi dengan berbagai kondisi, yaitu : saat sidik jari posisi tidak pas, sidik jari atau sensor kotor, sidik jari atau sensor berminyak, dan jari tangan dalam kondisi basah. Hasil eksperimen ditampilkan pada Tabel 2 berikut ini :

Tabel 2. Hasil Eksperimen

\begin{tabular}{cccccccc}
\hline $\begin{array}{c}\text { Sidik } \\
\text { Jari }\end{array}$ & $\begin{array}{c}\text { Jumlah } \\
\text { Eksperimen }\end{array}$ & $\begin{array}{c}\text { Terdeteksi } \\
\text { Benar }\end{array}$ & $\begin{array}{c}\text { Terdeteksi } \\
\text { Salah }\end{array}$ & Error & $\begin{array}{c}\% \\
\text { Benar }\end{array}$ & $\begin{array}{c}\% \\
\text { Salah }\end{array}$ & $\begin{array}{c}\% \\
\text { Error }\end{array}$ \\
\hline 1 & 20 & 17 & 2 & 1 & $85 \%$ & $10 \%$ & $5 \%$ \\
\hline 2 & 20 & 15 & 2 & 3 & $75 \%$ & $10 \%$ & $15 \%$ \\
\hline Total & 40 & 32 & 4 & 4 & $80 \%$ & $10 \%$ & $10 \%$ \\
\hline
\end{tabular}

Berdasarkan Tabel 2 dapat dijelaskan bahwa tingkat keberhasilan untuk sistem absensi ini sebesar $80 \%$. Ketidakberhasilan sebesar $20 \%$ diperoleh dari error $10 \%$ dan kesalahan pemindaian oleh sensor sidik jari sebesar 10\%. Error dapat karena hal teknis seperti gagalnya aliran listrik rangkaian, disebabkan karena rangkaian pada prototipe ini dipasang belum secara permanen sehingga ada beberapa kondisi kabel jumper lepas. Sedangkan untuk \% kesalahan terjadi karena gagalnya sensor AS608 dalam memindai sidik jari yang ditempel. 
Eksperimen juga memberikan hasil bahwa akurasi pemindai sidik jari diperoleh sebesar $89,89 \%$ yang diperoleh dari perhitungan sebagai berikut. Hasil analisis pada tingkat kesalahan pada pada sensor ini dikarenakan 2 hal yaitu kotornya sidik jari yang ditempel serta ketidakpasan sidik jari saat menempelkan ke sensor AS608. Dengan persentase masing-masing sebesar $25 \%$ dan $75 \%$. Sehingga dapat disimpulkan bahwa kelemahan pada sistem absensi ini adalah, jika siswa melakukan absensi dengan posisi sidik jari tidak pas $100 \%$ menempel pada sensor maka absen pada saat itu tidak akan masuk dalam sistem dan notifikasi tidak akan terkirim ke orang tua. Namun, untuk mengatasi hal tersebut peneliti menambahkan lcd untuk menampilkan kondisi apakah absen sudah berhasil atau belum.

Sistem absensi ini sudah efektif karena keakuratan sudah mencapai 89\%, sehingga sudah layak digunakan. Untuk meningkatkan akurasi hingga 100\% maka perlu dilakukan sosialisasi ke siswa untuk bagaimana cara melakukan absensi secara benar.Dengan adanya sistem absensi ini diharapkan dapat mengatasi masalah yang telah dijelaskan pada bab sebelumnya. Absensi ini juga dilengkapi dengan rekap melalui dashboard pada website yang mana hal tersebut dapat mempermudah guru yang bertugas untuk melihat rangkuman absensi muridnya secara realtime. Namun, sistem absensi masih sangat sederhana apstinya perlu adanya inovasi untuk pengembangan yang lebih lanjut.

\section{KESIMPULAN}

Beberapa kesimpulan dari Sistem Kehadiran Biometrik menggunakan sidik jari yaitu :

1. Sistem berhasil mengintegrasikan absensi menggunakan sidik jari dengan Telegram.

2. Rata-rata akurasi dari sistem kehadiran biometrik di angka $80 \%$ dengan tingkat kesalahan sebesar 20\% yang disebabkan oleh sistem error sebesar 10\% dan kesalahan pemindaian sidik jari sebesar $10 \%$.

3. Penyebab sistem error adalah karena hal teknis seperti kabel jumper lepas dan aliran listrik terputus.

4. Seluruh data absensi siswa disimpan di database dan memiliki user interface berupa website yang bisa diakses oleh siswa, guru, maupun orang tua siswa.

\section{DAFTAR PUSTAKA}

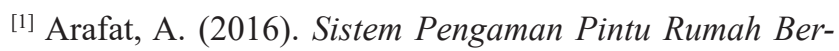
basis Internet Of Things(IoT) dengan ESP8266 (Vol. 7). Jurnal Ilmiah Fakultas Teknik "Technologia".

${ }^{[2]}$ Pratama, N. P., Triayudi, A., \& Hidayatulloh, D. (2019). Design-Based Fingerprint Time Attendance System Using IOT With MCU Node ESP8266 (Vol. 11). Jurnal Teknik Informatika C.I.T.

${ }^{[3]}$ Jain, T., Tomar, U., Arora, U., \& Jain, S. (2020). IoT
Based Biometric Attendance System (Vol. 11). International Journal of Electrical Engineering \& Technology (IJEET).

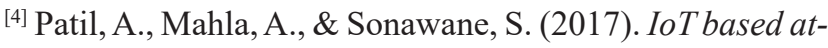
tendance system (Vol. 4). International Research Journal of Engineering and Technology(IRJET).

[5] PGSD, Universitas PGRI Yogyakarta. (2018, Juni 08). Pengertian Pendidikan. PGSD Universitas PGRI Yogyakarta. Retrieved Mei 4, 2021, from https:// pgsd.upy.ac.id/ 